\title{
When a bruise gets important: Bednar tumour
}

\author{
Filipa Tavares Almeida, ${ }^{\oplus 1}$ Sofia Daniela Carvalho, ${ }^{2}$ Teresa Pereira, ${ }^{1}$ Celeste Brito ${ }^{1}$
}

'Dermatovenereology, Hospital de Braga, Braga, Portugal ${ }^{2}$ Surgical Pathology, Hospital de Braga, Braga, Portugal

\section{Correspondence to} Dr Filipa Tavares Almeida, filipa.almeida6@hotmail.com

Accepted 25 January 2019

\section{DESCRIPTION}

A healthy 31-year-old woman was referred to our department due to a hyperpigmented lesion, similar to a bruise, with a 6-year history and progressive growth, that has never disappeared. There was no trauma history. Physical examination revealed a violaceous plaque, with $10 \mathrm{~mm}$ of diameter, located on the left shoulder (figure 1). Dermoscopy revealed a violaceous background in conjunction with blue-whitish veil lesions without a peripheral pigment network, and fine linear vessels, equally distributed all over the surface of the lesion (figure 2). An incisional biopsy was performed and histological examination revealed a neoplasia composed of spindle cells arranged in a storiform pattern, some of them pigmented. Immunohistochemical study showed intense and diffuse expression of CD34 by neoplastic cells (figure 3C) and S100 protein by pigmented spindle cells (figure $3 \mathrm{D}$ ). These results were compatible with a pigmented dermatofibrosarcoma protuberans (figure 3A,B). The patient underwent wide surgical excision. Thoraco-abdomino-pelvic CT scan was unremarkable. Currently, the patient is under regular follow-up, without any recurrence at 2 years.

Dermatofibrosarcoma protuberans (DFSP) is a rare cutaneous soft tissue sarcoma of intermediate malignancy, whose incidence peaks between the fourth and fifth decades of life. Bednar tumour, also known as pigmented DFSP, is a rare variant, accounting for less than $5 \%$ of all DFSP cases. ${ }^{1}$ It has a predisposition to affect the trunk, especially the back and shoulders, as seen in our case. Although it has significant subclinical extension and great capacity for local destruction and relapse, overall prognosis is favourable with prolonged survival and low rate of metastasis. ${ }^{2}$

The diagnosis of this tumour is difficult, as it can be mistaken, both clinically or histologically,

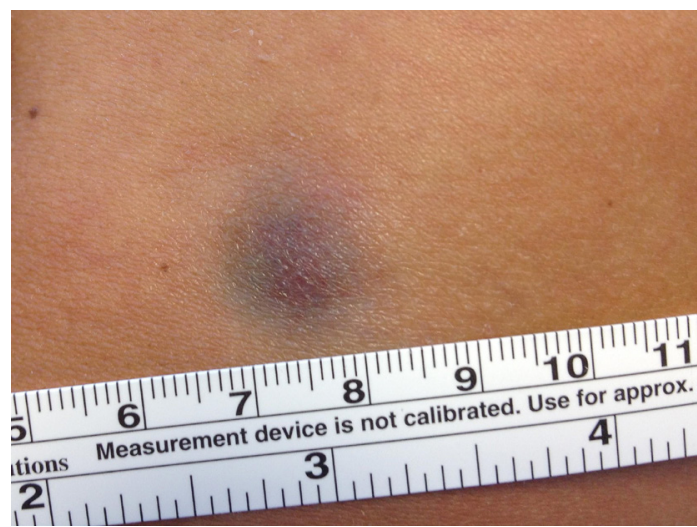

Figure 1 Bednar tumour located on the left shoulder.

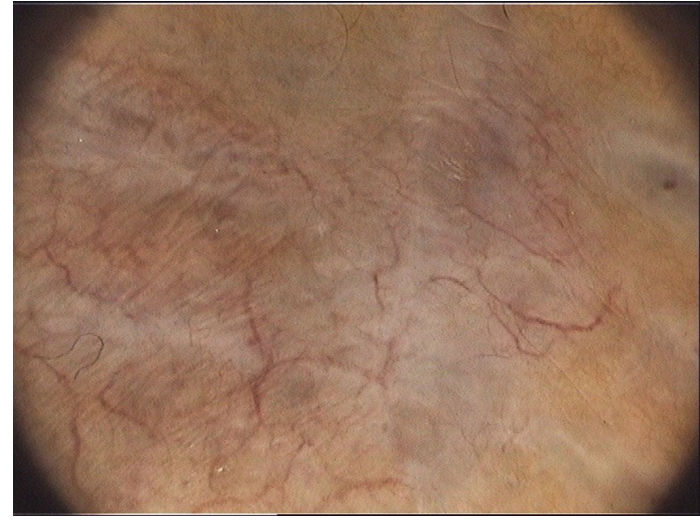

Figure 2 Dermoscopy of Bednar tumour.

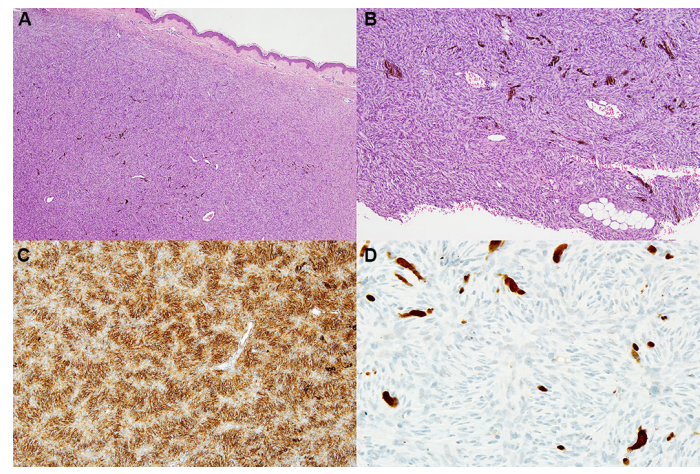

Figure 3 Microphotograph showing diffuse infiltration of dermis $(A, H \& E \times 40)$ and subcutis $(B, H \& E \times 100)$ by neoplasia composed of spindle cells arranged in a storiform pattern. Some spindle cells are pigmented. Neoplastic cells are immunopositive for CD34 $(C, \times 100)$ and pigmented spindle cells show expression of $\mathrm{S} 100$ protein $(D, \times 400)$.

for other skin tumours, including dermatofibroma, cellular blue nevus, fibrosarcoma and malignant melanoma. ${ }^{3}$ Therefore, any lesion with a prolonged evolution or that does not resolve spontaneously, even if clinically unsuspected, should always be biopsied to exclude malignancy.

\section{Learning points}

Bednar tumour is an uncommon pigmented subtype of dermatofibrosarcoma protuberans.

- It usually affects the trunk of young to middleaged adults.

- As clinical presentation may be heterogeneous, it is important to be aware of this entity and to perform histopathological analysis to make an early diagnosis. 
We reported this case because of its rarity and unusual presentation and to highlight the importance of histological examination with immunohistochemical study to warrant a prompt and correct diagnosis and to provide an adequate management of the patient.

Contributors The authors FTA, TP and CB contributed to the planning, conduction and report of the work. The authors FTA, SDC and TP contributed to the conception and design of the work. The authors FTA, SDC and TP contributed to the acquisition of analysis and interpretation of the results.

Funding The authors have not declared a specific grant for this research from any funding agency in the public, commercial or not-for-profit sectors.
Competing interests None declared.

Patient consent for publication Obtained.

Provenance and peer review Not commissioned; externally peer reviewed.

\section{REFERENCES}

1 Bernard J, Poulalhon N, Argenziano G, et al. Dermoscopy of dermatofibrosarcoma protuberans: a study of 15 cases. Br J Dermatol 2013;169:85-90.

2 Amonkar GP, Rupani A, Shah A, et al. Bednar Tumor: An Uncommon Entity. Dermatopathology 2016;3:36-8.

3 Kaul R, Kaur N, Dogra SS, et al. Variant of dermatofibrosarcoma protuberans: bednar tumor. Indian J Dermatol 2015;60:107.

Copyright 2019 BMJ Publishing Group. All rights reserved. For permission to reuse any of this content visit

https://www.bmj.com/company/products-services/rights-and-licensing/permissions/

BMJ Case Report Fellows may re-use this article for personal use and teaching without any further permission.

Become a Fellow of BMJ Case Reports today and you can:

- Submit as many cases as you like

Enjoy fast sympathetic peer review and rapid publication of accepted articles

Access all the published articles

Re-use any of the published material for personal use and teaching without further permission

For information on Institutional Fellowships contact consortiasales@bmjgroup.com

Visit casereports.bmj.com for more articles like this and to become a Fellow 